\title{
First genetic data for the Critically Endangered Cuban endemic Zapata Rail Cyanolimnas cerverai, and the taxonomic implications
}

\author{
Alex F. Brown'1, Thomas J. Shannon'1, J. Martin Collinson', Guy M. Kirwan², \\ Arturo Kirkconnell ${ }^{4}$ \& Martin Stervander ${ }^{2}$
}

ORCID id: 0000-0002-8111-475X (JMC), 0000-0002-6876-9452 (GMK), and 0000-0002-6139-7828 (MS)

${ }^{1}$ University of Aberdeen, School of Medicine, Medical Sciences and Nutrition, Institute of Medical Sciences, Aberdeen AB25 2ZD, UK.

2 Bird Group, Natural History Museum, Akeman Street, Tring, Hertfordshire HP23 6AP, UK.

${ }^{3}$ Field Museum of Natural History, 1400 South Lakeshore Drive, Chicago, IL 60605 USA.

423520 SW, 107 CT, Homestead, FL 33032, USA.

Correspondence: GMKirwan@aol.com (GMK) and martin@stervander.com (MS)

\section{KEYWORDS}

mitochondrial phylogeny

cytochrome oxidase I

historic DNA

Cuba

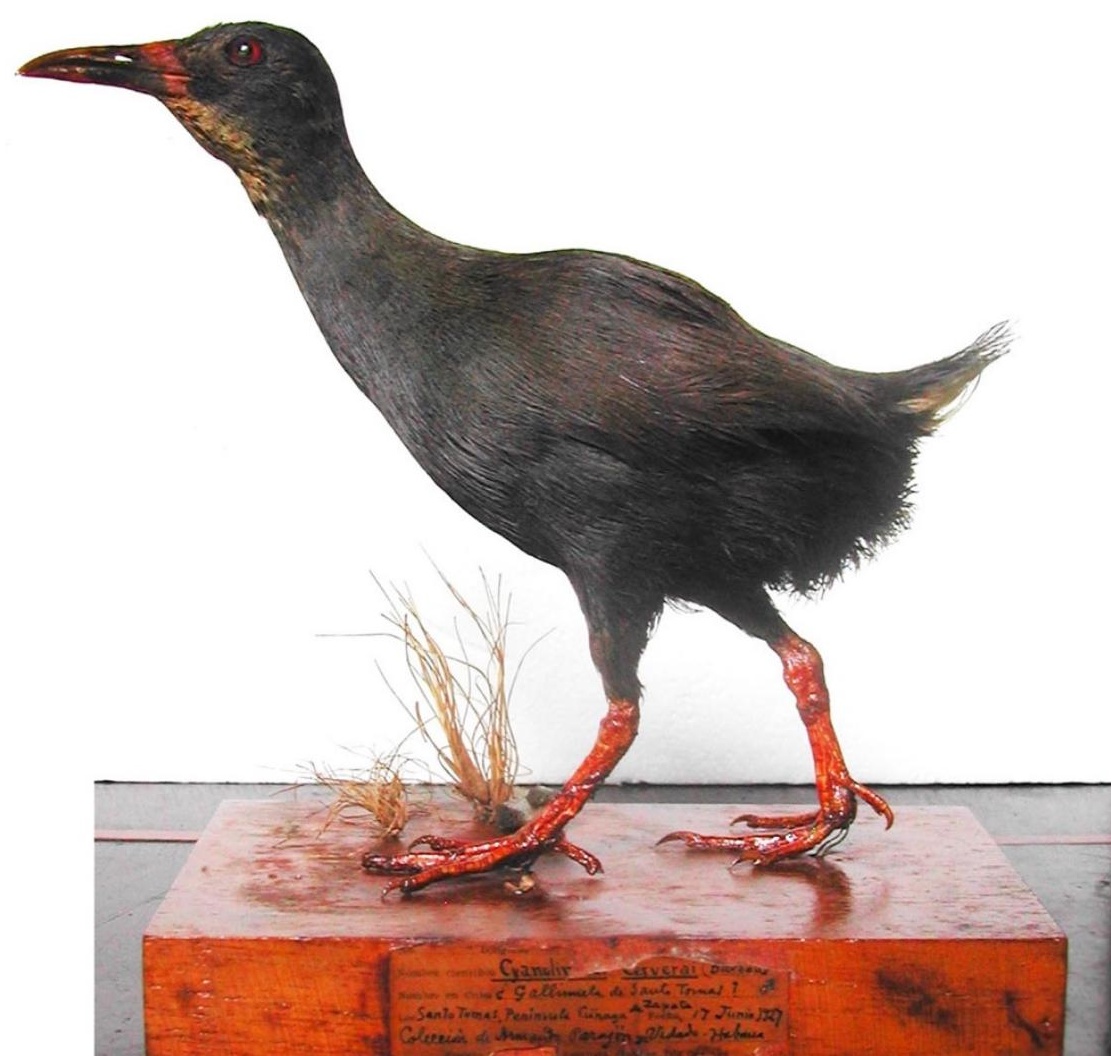




\section{ABSTRACT}

The taxonomic affinity of the near-flightless Zapata Rail Cyanolimnas cerverai, a Critically Endangered and highly localized species endemic to Cuba, has long been debated.

Morphological analyses have suggested that this species, which constitutes a monotypic genus, could be related either to the extinct Tahitian Cave Rails (Nesotrochis sp.) or to the South American rail tribe Pardirallini, i.e., the genera Neocrex, Mustelirallus, and Pardirallus. Whilst pronounced phenotypic convergence-and divergence-among rails have repeatedly proven morphology-based phylogenies unreliable, thus far no attempt to sequence DNA from the enigmatic Cyanolimnas has succeeded. In this study, we extracted historic DNA from a museum specimen collected in 1927 and sequenced multiple short fragments that allowed us to assemble a partial sequence of the mitochondrial cytochrome oxidase I gene. Phylogenetic analyses confirm that Cyanolimnas belongs in tribe Pardirallini as sister to genus Neocrex, from which it diverged about six million years ago. Their divergence from Mustelirallus was estimated at about eight million years ago. Based on morphology and our mitochondrial phylogeny, we conclude that it is unjustified to retain the monotypic genus Cyanolimnas and tentatively recommend that $C$. cerverai and the two Neocrex species are ascribed to genus Mustelirallus.

\section{INTRODUCTION}

The Critically Endangered Zapata Rail Cyanolimnas cerverai is endemic to Cuba and unquestionably is one of the most poorly known birds in the West Indian region (Kirwan et al. 2019, Kirkconnell et al. 2020, Taylor et al. 2020). Its declining population is apparently threatened by dry-season burning of its marsh habitat, predation by introduced small Indian mongooses (Herpestes auropunctatus), black rats (Rattus rattus) and African Catfish Clarias gariepinus (Collar et al. 1992, Kirkconnell 2012, Taylor et al. 2020), and habitat change engendered by the spread of the invasive broad-leaved paperback (Melaluca quinquenervia). Nowadays, this rail is known from just six closely spaced localities in the northern Ciénaga de Zapata (Matanzas province) in south mainland Cuba, based on 14 specimens collected between 1927 and 1934 (all but one in four US museums), and a relatively small number of sight records since 1979, most recently in November 2014 (Kirkconnell et al. 2020). However, fossil material of Cyanolimnas cerverai dating from the Holocene has been identified from Cueva de Pío Domingo, Sumidero, and Cueva El Abrón, Sierra de La Güira (Pinar del Río province), Cueva de Paredones and Cueva de Sandoval (Artemisa province), Calabazar (La Habana province), Cueva de Insunsa, Cuevas de Las Charcas and Cueva del Indio (all in Mayabeque province), near Jagüey Grande (Matanzas province), Cueva de Humboldt and Cueva del Salón (Sancti Spíritus province), and the Sierra 
de Caballos in the northern Isle of Pines (Olson 1974, Arredondo 1984, Suárez in press), i.e., over a much larger area than the known modern range.

Genus Cyanolimnas Barbour \& J. L. Peters, 1927, has always been considered monospecific, and was described as "A medium-sized ralline with short rounded wing; very short tail, the barbs of the rectrices very sparse; tarsus stout and short, not exceeding middle toe with claw. Bill moderate, somewhat longer than head, swollen basally. ... The combination of short wing and stout tarsus suggests relationships with Nesotrochis Wetmore [a genus comprising three large, flightless, extinct species from the Greater Antilles] ... but the latter has a tarsus more than twice as long" (Barbour \& Peters 1927). Ridgway \& Friedmann (1941) proffered a detailed morphological description of this genus, and thought it was apparently flightless. However, whilst Cyanolimnas has reduced powers of flight, it is volant (AK pers. obs.), and in any case flightlessness is now known to have arisen many times in Rallidae and cannot be used as a predictor of relationships (e.g., Olson 1973, Slikas et al. 2002, Kirchman 2012, Gaspar et al. 2020, Garcia-R \& Matzke 2021, although Cyanolimnas was incorrectly treated as flightless in the latter). As noted by Olson (1973) and Steadman et al. (2013), in its robust, deep-based bill Cyanolimnas is similar to the two species frequently assigned to Neocrex Sclater \& Salvin, 1868, Colombian Crake N. colombiana and Paint-billed Crake N. erythrops (both of which are now often placed in an expanded Mustelirallus Bonaparte, 1856; e.g., Kirchman et al. 2021). Plumage and osteological characters are similar to either Neocrex, or less so to the latter's sister taxon Pardirallus Bonaparte, 1856, to which genus Cyanolimnas was considered most closely related in the morphological phylogenies of Livezey (1998) and Garcia-R \& Matzke (2021).

Its ecology and natural history are virtually unknown; for example, a nest with eggs ascribed to Cyanolimnas, found in early September 1982 (Bond 1984), seems unlikely to have been identified correctly (Kirkconnell et al. 2020), and even this rail's voice is unknown. A published sound recording, originally believed to pertain to Cyanolimnas (Reynard \& Garrido 1988, Hardy et al. 1996), is now identified as belonging to Spotted Rail Pardirallus maculatus, which is a rather abundant species in the Ciénaga de Zapata (Kirkconnell et al. 2020). During NovemberDecember 1998 a survey using the published sound recording as a tool estimated a population of 70-90 individuals of Cyanolimnas (Kirkconnell et al. 1999). Subsequently, it was realised that the recording actually involved P. maculatus (Kirkconnell et al. 2005) and that the description of Cyanolimnas vocalizations in Kirkconnell et al. (1999) was erroneous. Inferences concerning the relationships of Cyanolimnas based on ecology or vocalizations are consequently impossible.

To date, just one molecular phylogenetic study, using ultra-conserved elements (UCEs), has attempted to ascertain the relationships of Cyanolimnas (using a toe pad from AMNH 300416, a female collected by P. Quintaña in April 1934), but was unsuccessful in yielding any UCEs, and 
consequently failed to place the species (Kirchman et al. 2021). As a result, Kirchman et al. (2021) proposed to treat Cyanolimnas as genus incertae sedis; the aim of the present work is to address this shortfall in knowledge.

\section{METHODS}

\section{Primer design and evaluation}

We obtained cytochrome oxidase I (COI) sequences of rallid species NCBI/GenBank (https://www.ncbi.nlm.nih.gov/nucleotide/), aligned these sequences using CLC Sequence viewer v6.0 (QIAGEN; UK) (https://digitalinsights.qiagen.com/products/clc-sequence-viewerdirect-download/) and identified regions of high similarity and roughly 50\% GC content. We manually designed degenerated primers of 21-23 bp length to produce $<200 \mathrm{bp}$ fragments from the degraded DNA (Table 1) and tested the primer pairs on Common Moorhen Gallinula chloropus and Allen's Gallinule Porphyrio alleni in order to preserve the DNA from the Zapata Rail.

Table 1. Primers designed for the Zapata Rail COI gene. This table lists all the PCR primers designed to amplify the DNA sequence of the Zapata Rail's COI gene.

\begin{tabular}{lll}
\hline Primer pair & Primer name & Primer sequence $\left(5^{\prime}-3^{\prime}\right)$ \\
\hline 1 & ZRCOIF1a & CTAACCACAAAGACATCGGAAC \\
& ZRCOIR1 & CCGCCCATGCCTTCGTAATA \\
2 & ZRCOIF2 & TACTYCTAGCYTCCTCTACAG \\
& ZRCOIR2 & TCAACTTCATCACAACCGCC \\
$2 \mathrm{a}$ & ZRCOIF2a & GCTATCAACTTCATCACAACCG \\
& ZRCOIR2a & CGCTGGCATCACCATACTACT \\
4 & ZRCOIF4 & CYGCCCATGCYTTCGTAATA \\
& ZRCOIR4 & TTCCTCTACAGTAGAAGCAG \\
5 & ZRCOIF5 & AGCCTRCTYATCCGAGCAGA \\
& ZRCOIR5 & CCCCAGACATAGCATTTCCC \\
\end{tabular}

\section{Sampling and laboratory procedures}

We obtained a toepad sample of Zapata Rail from the Museo de Historia Natural 'Felipe Poey', La Habana, Cuba (MFP 14.000218) and extracted DNA using QIAGEN QIAamp® DNA microkit, following the manufacturer's instructions, modified for digestion overnight at $56^{\circ} \mathrm{C}$ and repeated vortexing. The DNA was eluted in $80 \mu \mathrm{l}$ Buffer AE. 
We set up $50 \mu \mathrm{l}$ PCR reactions using $2.5 \mu \mathrm{l}$ template DNA and $47.5 \mu \mathrm{l}$ PCR mastermix made from $5 \mu \mathrm{l}$ of $10 \times$ OptiBuffer (Bioline Reagents Ltd, UK), $2.5 \mu \mathrm{l}$ of primer at $10 \mu \mathrm{M}, 1 \mu \mathrm{l} 50 \mathrm{mM}$ magnesium chloride, 0.6 $\mu 10$ mM DNT mix (Sigma, Poole, UK), 0.5 $\mu$ l BIO-X-ACT short DNA

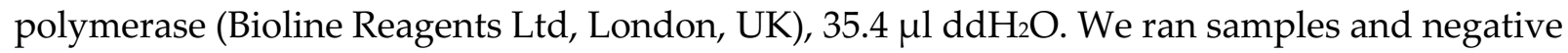
controls in PCR programs following Hebert et al. (2004), with a low annealing temperature in first 5 cycles to accommodate potential primer-sample mismatches: denaturing $60 \mathrm{~s}$ at $94^{\circ} \mathrm{C}$, annealing $60 \mathrm{~s}$ at $45^{\circ} \mathrm{C}$, and extension $50 \mathrm{~s}$ at $72^{\circ} \mathrm{C}$. For the following $30 \mathrm{cycles}$, the annealing temperature was increased to $51^{\circ} \mathrm{C}$.

Four $\mu \mathrm{l}$ 100-bp DNA ladder (Promega, Southampton, UK) and $40 \mu \mathrm{l}$ of the PCR products were loaded with $5 \mu$ l Promega $6 \times$ DNA loading dye on 1.5\% agarose gels (peqGOLD universal agarose; Peqlab, Fareham UK), stained with 1-2 $\mu$ l ethidium bromide, in 1× TAE buffer. We ran the electrophoresis at $86 \mathrm{~V}, 100 \mathrm{~mA}$ for 20-40 minutes, inspected the gel under UV light, and cut our bands of expected size with a scalpel. The PCR product was isolated from gel fragments with a Gel Extraction Kit (Qiagen, Manchester, UK), following the manufacturer's instructions, and eluted in $30 \mu \mathrm{l}$ elution buffer EB. We quantified the purified PCR product with a Nanodrop spectrophotometer and diluted the PCR products to $10 \mu \mathrm{g} / \mu \mathrm{l}$, after which they were bidirectionally Sanger sequenced by Source Bioscience (Nottingham, UK).

\section{Phylogenetic analyses}

We initially scrutinized the sequences using FinchTV (Geospiza Inc.) and then assembled them to the rallid sequence set used for primer design in CLC Sequence Viewer 8 (https://www.qiagenbioinformatics.com/products/clc-sequence-viewer/), followed by extraction of the 601-bp long overlapping Zapata Rail COI consensus sequence. We then obtained a larger set of 450 COI sequences of extant taxa within the order Gruiformes from GenBank, and additionally included sequence data from ancient DNA of the extinct Nesotrochis steganinos (Oswald et al. 2020), because of its proposed close relationship to Cyanolimnas in combination with its recent extinction (Oswald et al. 2020 dated bones to 6,430 \pm 30 years before present). We aligned sequences with MAFFT (Katoh \& Standley 2013) in Geneious v. 10.2.6 (Kearse et al. 2012) and selected $\leq 3$ per taxon based on length and quality (for taxa and accession numbers, see Table S1). We further trimmed this dataset to a 962-bp region that maximized overall sequence coverage and fully overlapped the Zapata Rail COI sequence (see Data Availability). We employed the greedy algorithm (Lanfear et al. 2012) in PartitionFinder2 (Lanfear et al. 2016) to evaluate the full set of SNA substitution models and explore optimal partitioning with regard to codon position, using PhyML (Guindon et al. 2010). The best partitioning scheme by AICc was identified as individual substitution models per codon position: the general time-reversible (GTR; Tavaré 1986) model with the among-site rate variation following a gamma $(\Gamma)$ 
distribution and with a proportion of invariant sites (I) for position 1, the transversion model $(\mathrm{TVM})+\Gamma+\mathrm{I}$ for position 2 , and the transition model $(\mathrm{TiM})+\Gamma+\mathrm{I}$ for position 3 .

We implemented the partitioning scheme in Beast v. 2.6.6 (Bouckaert et al. 2014) using the plugin SSM v. 1.1.0 and set the proportion of invariant sites to be estimated, and the $\Gamma$ distribution to be estimated across four rate categories. Employing a birth-death speciation model, we set the prior for death rate to follow an exponential distribution with mean 1 . We enforced monophyly of the clades Rallidae, Ralloidea, and Gruoidea, and employed dating calibration priors on Gruiformes and stem Rallidae following Chaves et al. (2020). We then ran two iterations of 10 million generations, sampling every 1,000 generations, and optimized tuning parameters and operator weights to produce the final $\mathrm{xml}$ specification used for our analyses (see Data Availability). We ran five replicate analyses at different seeds in Beast, sampling every 1,000 generation for 20-60 million generations, until inspection in Tracer v. 1.7.1 (Rambaut et al. 2018) revealed stationarity and sufficient effective samples sizes (all parameters >200). Some substitution model-related parameters for codon position 1 and to some degree 2 (specific substitution rates, gamma shape, and proportion invariant sites) seemed to have dual optima, with shifting within and between replicates. Thus, replicates converged in either of two groups; however, this had no impact on the topology, support, or dating of the focal clade. We calculated maximum clade credibility trees with mean node heights after discarding $5-50 \%$ as burn-in.

In addition to the Bayesian inference (BI) with Beast, we also used IQtree v. 2.1.2 (Lanfear et al. 2020) for phylogenetic analyses based on maximum likelihood (ML). We applied the partitioning and substitution model scheme determined with PartitionFinder2 and ran 1,000 ultrafast bootstrap replicates.

\section{RESULTS}

All phylogenetic analyses placed Cyanolimnas as sister to N. erythrops, the pair of which was sister to the Ash-throated Crake Mustelirallus (formerly Porzana) albicollis (Figure 1). These three taxa formed a sister clade to the genus Pardirallus (Figure 1). There was near-full support for a Pardirallus-Mustelirallus-Neocrex-Cyanolimnas clade (posterior probability (PP) 1.0 in the BI analyses and 99\% ultrafast bootstrap support (UFB) in the ML analyses). The exact placement of Cyanolimnas as sister to Neocrex received full support (UFB 100\%) in the ML analyses and PP 0.86 with BI (Figure 1). There were some differences in inferred topology between BI replicates (see Data Availability); however, none of these occurred within the focal PardirallusMustelirallus-Neocrex-Cyanolimnas clade. 
bioRxiv preprint doi: https://doi.org/10.1101/2022.02.07.477705; this version posted February 10, 2022. The copyright holder for this preprint (which was not certified by peer review) is the author/funder, who has granted bioRxiv a license to display the preprint in perpetuity. It is made available under aCC-BY-NC 4.0 International license.

The inferred mean age of split between Cyanolimnas and Neocrex was 5.9 MA (95\% highest posterior density 2.8-9.4 MA), between those and Mustelirallus 8.1 (4.4-12.0) MA, and between that clade and Pardirallus 10.6 (6.6-15.2) MA (Figure 1).

Nesotrochis was recovered as a sister lineage to Sarothruridae (Figure 1).

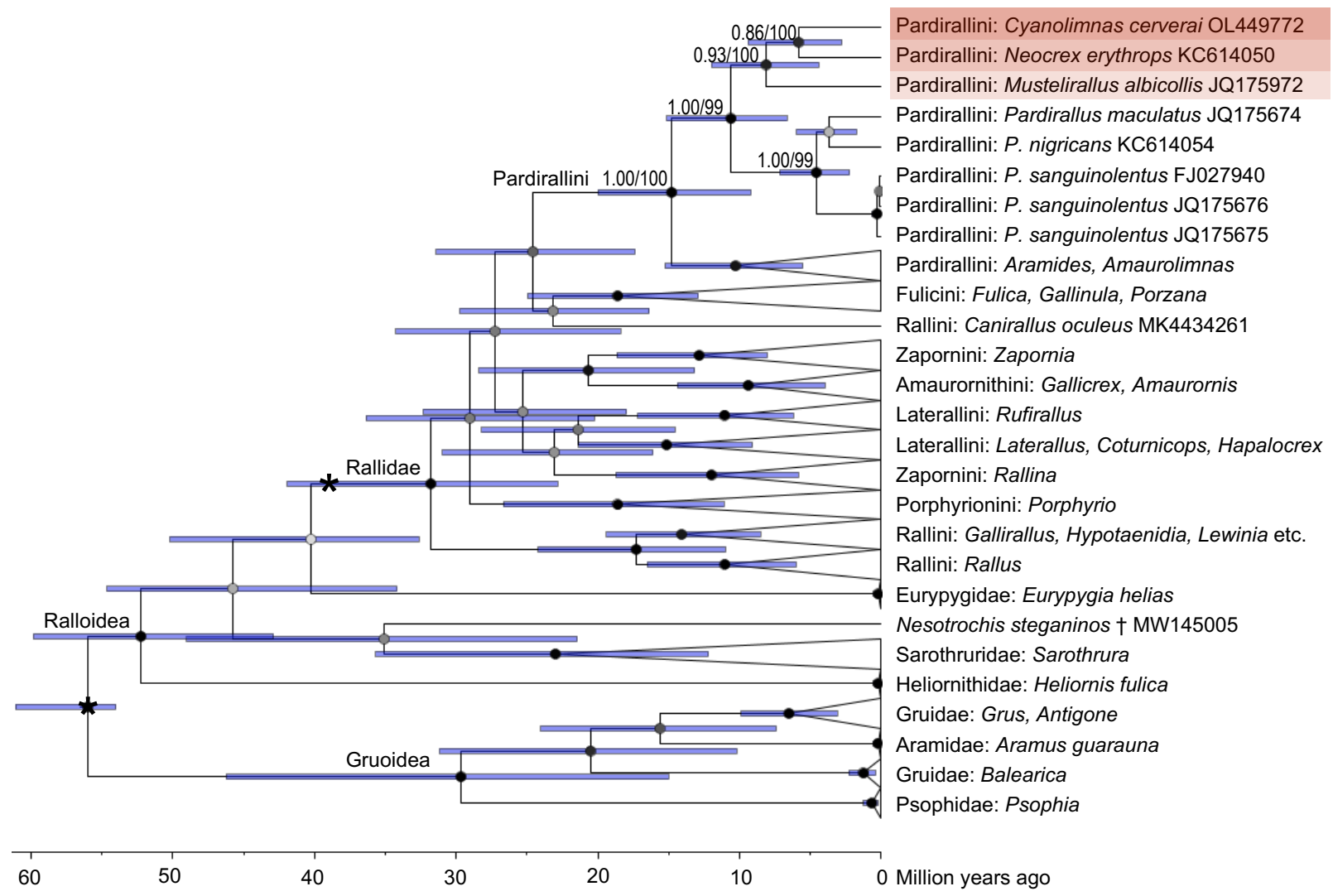

Figure 1. Phylogenetic tree of Gruiformes, based on mitochondrial cytochrome oxidase I (COI) sequences, analyzed with Bayesian inference (BI) in Beast. Posterior probability is indicated by node colour ( 0.0 = white; 1.0 = black) and specified with labels at nodes for the focal clade in tribe Pardirallini (first number), together with ultrafast bootstrap support values (0-100) from maximum likelihood (ML) analyses with IQtree (second number). The asterisks at the root of Gruiformes and the stem of Rallidae indicate fossil calibration points. Non-focal clades represented by multiple sequences have been collapsed and labelled according to Kirchman et al. (2021) with tribe (for Rallidae) or family (outside Rallidae) followed by species or genus (if multiple species). For non-collapsed replicate BI trees and ML tree, see Data Availability.

\section{DISCUSSION}

We provide the first genetic data for Cyanolimnas, as the species has not been included or successfully sequenced by any previous molecular-phylogenetic study of the Rallidae (e.g., Garcia-R et al. 2014, Garcia-R \& Matzke 2021, Kirchman et al. 2021), which led Kirchman et al. (2021) to consider its placement 'incertae sedis'. It should be stressed that the reliability of 
phylogenies based on single genetic markers is limited, and this is particularly true for mitochondrial markers. The fast-evolving mitochondrion occurs with multiple copies per cell and has historically been widely used for molecular phylogenies, and further remains important for genetic barcoding. However, for several reasons the mitochondrial phylogenetic signal may be discordant from that of the nuclear genome (e.g., through introgression) and reflect an evolutionary trajectory different from 'true' speciation events (Toews \& Brelsford 2012). In our analyses, for example, the COI tree renders Gruidae paraphyletic with respect to Aramidae (Figure 1). Nevertheless, mitochondrial data are relevant for a first test of presumed phylogenetic context, and yield useful relative divergence times.

Similar to the whole-mitochondrion analyses by Oswald et al. (2020), our analyses of COI placed Nesotrochis outside Rallidae, separated from Cyanolimnas by some 45 million years (Figure 1). Our data instead provide strong support for the previous hypotheses rooted in morphological traits that have placed Cyanolimnas in what has been referred to as the 'Aramides clade' (Livezey 1998, Garcia-R et al. 2014, Garcia-R \& Matzke 2021), better termed tribe Pardirallini sensu Kirchman et al. (2021). Within this grouping, the species appears to be most closely related to $N$. erythrops and M. albicollis, but less so to the three species of Pardirallus, in partial congruence with prior predictions (Olson 1973, Livezey 1998, Garcia-R \& Matzke 2021). Although it is now rather well established that plumage is not necessarily a reliable character for inferring phylogenetic relationships within the Rallidae (e.g., Garcia-R et al. 2014, Stervander et al. 2019, Chaves et al. 2020), in the present case morphology appears to be rather informative.

The key question that arises is whether the separate monospecific genus Cyanolimnas is warranted? The age of the split between Cyanolimnas and Neocrex (5.9 MA) is comparatively young relative to many other Rallidae, a family that contains several old generic clades (e.g., Aramides 7.4 MA, Porzana 9.8 MA, Rallus 11.0 MA, Rallina 12.0 MA, Zapornia 12.9 MA, and Porphyrio 18.6 MA based our COI analyses; Fig. 1). However, some clades contain even younger taxa, for example the Eulabeornis-Cabalus-Gallirallus-Hypotaenidia group of the Rallini (which arose 3.4-4.1 MA), all or most of which genera are accepted by some authorities (e.g., Dickinson \& Remsen 2013, del Hoyo \& Collar 2014, Kirchman et al. 2021). Nevertheless, in the latter case these four genera are sometimes treated alternatively as a single genus, for which the name Gallirallus Lafresnaye, 1841, has priority (Kirchman 2012).

We consider that the available molecular and morphological evidence in combination strongly supports that C. cerverai be included in either genus Neocrex Sclater \& Salvin, 1869, or Mustelirallus, Bonaparte, 1856, given that its most divergent trait from either of these two, (near-)flightlessness, is well accepted to be not taxonomically informative (Olson 1973, Slikas et al. 2002, Kirchman 2012, Gaspar et al. 2020, Garcia-R \& Matzke 2021). Although N. colombiana, an 
exceptionally poorly known rallid of northwestern South America and easternmost Panama, has yet to be sampled genetically, to date there is no indication that it is not very closely related to N. erythrops (Wetmore 1967, Olson 1973, Taylor 1996). Following the lead of Kirchman et al. (2021), we recommend that, for the present, the most parsimonious approach is to treat all four species-Ash-throated Crake, Paint-billed Crake, Colombian Crake and, now, Zapata Rail-as members of a single genus, for which the name Mustelirallus (masculine) has priority. The new combinations are Mustelirallus albicollis, M. erythrops, M. colombianus, and M. cerverai. Kirchman et al. (2021) incorrectly listed Colombian Crake as M. columbianus, overlooking that Bangs' (1898) original spelling was Neocrex colombianus as noted by Dickinson \& Remsen (2013).

\section{Acknowledgements}

GMK and AK are grateful to staff, particularly Ianela García-Lau, Manolo Barro and volunteers at the Museo de Historia Natural 'Felipe Poey', La Habana, Cuba, for access to relevant specimens. This study was funded by University of Aberdeen (AB) and The Sound Approach Ph.D. Studentship (TJS).

\section{Author contributions}

Conceived and managed project: GMK, JMC, MS. Provided biological sample: AK, GMK. Designed primers, performed molecular lab work: AFB, TJS, JMC. Assembled COI sequence: AFB, TJS. Performed phylogenetic analyses: MS. Wrote the manuscript: GMK, MS.

\section{DATA AVAILABILITY}

The Zapata Rail COI sequence has been deposited at Genbank with accession number OL449772. Supporting material has been deposited at Zenodo and is available at https://doi.org/10.5281/zenodo.5805456. This includes Table S1 (taxon name, classification, and accession numbers for sequences included); sequence alignment nexus file; Beast xml input file; Beast output including maximum clade credibility tree files; log files and raw tree files; and IQtree consensus tree file.

\section{REFERENCES}

Arredondo O. 1984. Sinopsis de las aves halladas en depósitos fosilíferos pleisto-holocénicos de Cuba. Reporte de Investigacion del Instituto de Zoologia, Academia de Ciencias de Cuba 17: 1-35. Bangs O. 1898. On some birds from the Sierra Nevada de Santa Marta, Colombia. Proceedings of the Biological Society of Washington 12: 171-182.

Barbour T \& Peters JL. 1927. Two more remarkable new birds from Cuba. Proceedings of the New England Zoölogical Club 9: 95-97. 
Bond J. 1984. Twenty-fifth supplement to the check-list of birds of the West Indies (1956). Academy of Natural Sciences, Philadephia.

Bouckaert R, Heled J, Kuhnert D, Vaughan T, Wu CH, Xie D, Suchard MA, Rambaut A \& Drummond AJ. 2014. BEAST 2: A software platform for Bayesian evolutionary analysis. PLoS Computational Biology 10: e1003537. https://doi.org/10.1371/journal.pcbi.1003537

Chaves JA, Martinez-Torres PJ, Depino EA, Espinoza-Ulloa S, García-Loor J, Beichman AC \& Stervander M. 2020. Evolutionary History of the Galápagos Rail Revealed by Ancient Mitogenomes and Modern Samples. Diversity 12: 425. https://doi.org/10.3390/d12110425 Collar N, Gonzaga L, Krabbe N, Madroño Nieto A, Naranjo L, Parker III T \& Wege D. 1992. Threatened Birds of the Americas: The ICBP/IUCN Red Data Book. International Council for Bird Preservation, Cambridge, UK.

Dickinson E, Remsen Jr JV (eds). 2013. The Howard \& Moore Complete Checklist of the Birds of the World, vol 1, 4th edn. Aves Press, Eastbourne, UK.

Garcia-R JC, Gibb GC \& Trewick SA. 2014. Deep global evolutionary radiation in birds: Diversification and trait evolution in the cosmopolitan bird family Rallidae. Molecular Phylogenetics and Evolution 81: 96-108. https://doi.org/10.1016/j.ympev.2014.09.008

Garcia-R JC \& Matzke NJ. 2021. Trait-dependent dispersal in rails (Aves: Rallidae): Historical biogeography of a cosmopolitan bird clade. Molecular Phylogenetics and Evolution 159: 107106. https://doi.org/10.1016/j.ympev.2021.107106

Gaspar J, Gibb GC \& Trewick SA. 2020. Convergent morphological responses to loss of flight in rails (Aves: Rallidae). Ecology and Evolution 10: 6186-6207. https://doi.org/10.1002/ece3.6298

Guindon S, Dufayard J-F, Lefort V, Anisimova M, Hordijk W \& Gascuel O. 2010. New Algorithms and Methods to Estimate Maximum-Likelihood Phylogenies: Assessing the Performance of PhyML 3.0. Systematic Biology 59: 307-321.

https://doi.org/10.1093/sysbio/syq010

Hardy J, Reynard G \& Taylor T. 1996. Voices of the New World rails. ARA Records, Gainesville, FL.

del Hoyo J, Collar NJ, Christie DA, Elliott A, Fishpool LDC, Boesman P \& Kirwan GM. 2014. $H B W$ and BirdLife International Illustrated Checklist of the Birds of the World, vol 1: Nonpasserines. Lynx Edicions and BirdLife International, Barcelona, Spain and Cambridge, UK.

Jiménez O \& Orihuela J. 2021. Nuevos hallazgos de aves en contextos paleontológicos y arqueológicos de Cuba. Novitates Caribaea: 163-176.

Jiménez O \& Valdés P (eds). 1995. Los vertebrados fósiles de la Cueva del Indio, San José de las Lajas, Habana, Cuba. Pp. 62-63 in: Resúmenes de Congreso Internacional LV Aniversario de la Sociedad Espeleológica de Cuba. 
Katoh K \& Standley DM. 2013. MAFFT Multiple Sequence Alignment Software Version 7:

Improvements in Performance and Usability. Molecular Biology and Evolution 30: 772-780. https://doi.org/10.1093/molbev/mst010

Kearse M, Moir R, Wilson A, Stones-Havas S, Cheung M, Sturrock S, Buxton S, Cooper A, Markowitz S, Duran C, Thierer T, Ashton B, Meintjes P \& Drummond A. 2012. Geneious Basic: An integrated and extendable desktop software platform for the organization and analysis of sequence data. Bioinformatics 28: 1647-1649.

https://doi.org/10.1093/bioinformatics/bts199

Kirchman JJ. 2012. Speciation of flightless rails on islands: A DNA-based phylogeny of the typical rails of the Pacific. The Auk 129: 56-69. https://doi.org/10.1525/auk.2011.11096

Kirchman JJ, Rotzel McInerney N, Giarla TC, Olson SL, Slikas E \& Fleischer RC. 2021.

Phylogeny based on ultra-conserved elements clarifies the evolution of rails and allies (Ralloidea) and is the basis for a revised classification. Ornithology 138: ukab042. https://doi.org/10.1093/ornithology/ukab042

Kirkconnell A, González O, Alfaro E \& Cotayo L. 1999. Nuevas localidades para la Gallinuela de Santo Tomás Cyanolimnas cerverai y la Ferminia Ferminia cerverai en la Ciénaga de Zapata, Cuba. Cotinga 12: 57-60.

Kirkconnell A, Stotz DF, Shopland JM (eds). 2005. Cuba: Peninsula de Zapata. Rapid Biological Inventories Report 07. The Field Museum, Chicago, IL.

Kirkconnell A. 2012. Cyanolimnas cerverai Barbour y Peters. In: González Alonso H, Rodríguez Schettino L, Rodríguez A, Mancina CA \& Ramos García I (eds) Libro Rojo de los Vertebrados de Cuba. Instituto de Ecología y Sistemática, La Habana.

Kirkconnell A, Kirwan G, Garrido O, Mitchell A \& Wiley J. 2020. The Birds of Cuba, an Annotated Checklist. British Ornithologists' Club, Tring, UK.

Kirwan GM, Levesque A, Oberle MW \& Sharpe CJ. 2019. Birds of the West Indies. Lynx Edicions, Barcelona, Spain.

Lanfear R, Calcott B, Ho SYW \& Guindon S. 2012. PartitionFinder: Combined Selection of Partitioning Schemes and Substitution Models for Phylogenetic Analyses. Molecular Biology and Evolution 29: 1695-1701. https://doi.org/10.1093/molbev/mss020

Lanfear R, Frandsen PB, Wright AM, Senfeld T \& Calcott B. 2016. PartitionFinder 2: New Methods for Selecting Partitioned Models of Evolution for Molecular and Morphological Phylogenetic Analyses. Molecular Biology and Evolution 34: 772-773.

https://doi.org/10.1093/molbev/msw260

Lanfear R, von Haeseler A, Woodhams MD, Schrempf D, Chernomor O, Schmidt HA, Minh BQ \& Teeling E. 2020. IQ-TREE 2: New Models and Efficient Methods for Phylogenetic Inference in the Genomic Era. Molecular Biology and Evolution 37: 1530-1534. https://doi.org/10.1093/molbev/msaa015 
Livezey BC. 1998. A phylogenetic analysis of the Gruiformes (Aves) based on morphological characters, with an emphasis on the rails (Rallidae). Philosophical Transactions of the Royal Society of London B Biological Sciences 353: 2077-2151. https://doi.org/10.1098/rstb.1998.0353

Olson SL. 1973. A Classification of the Rallidae. Wilson Bulletin 85: 381-416.

Olson SL. 1974. A new species of Nesotrochis from Hispaniola, with notes on other fossil rails from the West Indies (Aves: Rallidae). Proceedings of the Biological Society of Washington 87: 439-450.

Oswald JA, Terrill RS, Stucky BJ, LeFebvre MJ, Steadman DW, Guralnick RP \& Allen JM. 2021. Ancient DNA from the extinct Haitian cave-rail (Nesotrochis steganinos) suggests a biogeographic connection between the Caribbean and Old World. Biology Letters 17: 20200760. https://doi.org/10.1098/rsbl.2020.0760

Rambaut A, Drummond AJ, Xie D, Baele G \& Suchard MA. 2018. Posterior Summarization in Bayesian Phylogenetics Using Tracer 1.7. Systematic Biology 67: 901-904.

https://doi.org/10.1093/sysbio/syy032

Reynard G \& Garrido O. 1988. Bird songs in Cuba. Cornell University Laboratory of Ornithology, Ithaca, NY.

Ridgway R \& Friedmann H. 1941. The birds of North and Middle North America, Part IX. Bulletin of the United States National Museum 50. https://doi.org/10.5962/bhl.title.54021

Rojas-Consuegra R, Jiménez O, Condis-Fernández M \& Díaz-Franco S. 2012. Tafonomía y paleoecología de un yacimiento paleontológico del Cuaternario en la Cueva del Indio, La Habana, Cuba. Espelunca digital 12: 1-12.

Slikas B, Olson SL \& Fleischer RC. 2002. Rapid, independent evolution of flightlessness in four species of Pacific Island rails (Rallidae): An analysis based on mitochondrial sequence data. Journal of Avian Biology 33: 5-14. https://doi.org/10.1034/j.1600-048X.2002.330103.x

Steadman D, Morris J \& Wright N. 2013. A new species of Late Pleistocene rail (Aves: Rallidae) from Abaco, the Bahamas. Paleontological Journal 47: 1355-1364.

Stervander M, Ryan PG, Melo M \& Hansson B. 2019. The origin of the world's smallest flightless bird, the Inaccessible Island Rail Atlantisia rogersi (Aves: Rallidae). Molecular Phylogenetics and Evolution 130: 92-98. https://doi.org/10.1016/j.ympev.2018.10.007

Suárez W. In press. Catalogue of Cuban fossil and subfossil birds. Bulletin of the British Ornithologists' Club 142.

Tavaré S. 1986. Some probabilistic and statistical problems in the analysis of DNA sequences. Lectures on Mathematics in the Life Sciences 17: 57-86.

Taylor PB. 1996. Family Rallidae (rails, gallinules and coots). Pp. 108-209 in: del Hoyo J, Elliott A \& Sargatal J (eds) Handbook of the Birds of the World, vol 3: Hoatzin to Auks. Lynx Edicions, Barcelona. 
Taylor B, Kirwan GM \& Sharpe C. 2020. Zapata Rail (Cyanolimnas cerverai), v 1.0. In: del Hoyo J, Elliott A, Sargatal J, Christie D \& de Juana E (eds) Birds of the World. Cornell Lab of Ornithology, Ithaca, NY. https://doi.org/10.2173/bow.zaprai1.01

Toews DPL \& Brelsford A. 2012. The biogeography of mitochondrial and nuclear discordance in animals. Molecular Ecology 21: 3907-3930. https://doi.org/10.1111/j.1365-294X.2012.05664.x

Wetmore A. 1967. Further systematic notes on the avifauna of Panama. Proceedings of the Biological Society of Washington 80: 229-242. 